\title{
III. Instrumentalização para a busca de veraz qualidade e de precisa cientificidade da educação a promover
}

\author{
Pedro Bergamo
}

\section{SciELO Books / SciELO Livros / SciELO Libros}

BERGAMO, P. Educação universitária: práxis coletiva em busca de veraz qualidade e de precisa cientificidade [online]. Campina Grande: EDUEPB, 2012. Instrumentalização para a busca de veraz qualidade e de precisa cientificidade da educação a promover. pp. 109-158. ISBN 978-85-7879-189-6. Available from SciELO Books <http://books.scielo.org $>$.

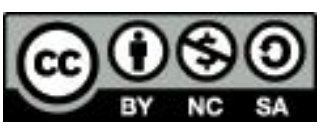

All the contents of this work, except where otherwise noted, is licensed under a Creative Commons Attribution-Non Commercial-ShareAlike 3.0 Unported.

Todo o conteúdo deste trabalho, exceto quando houver ressalva, é publicado sob a licença Creative Commons Atribuição Uso Não Comercial - Partilha nos Mesmos Termos 3.0 Não adaptada.

Todo el contenido de esta obra, excepto donde se indique lo contrario, está bajo licencia de la licencia Creative Commons Reconocimento-NoComercial-CompartirIgual 3.0 Unported. 


\section{Instrumentalização para a busca de veraz qualidade e de precisa cientificidade da educação a promover}

\section{A. A notícia sobre uma situação real-concretamente básica e inarredável}

A princípio, anuncia-se relação entre duas situações da condição já adulta do ser humano: (a) "situação epistêmica" que significa sobre-estar propriedades extrínsecas à pessoa como instrumento de se garantir autossustentação, ilimitadamente; e, (b) "situação hipostêmica" que traduz subestar tais propriedades enquanto condição autossustentatória.

Essa (anunciada) relação tem correspondido a mero vazio de saber e, por isso, este vazio incide na carência de razão para existirem as duas situações. Estas, por sua vez, refletem necessidades de conhecer fontes do que apropriar no exterior da condição adulta do ser humano. Então, o confronto das diferenças correspondentes a tais necessidades também há de perfazer razão de existir aquele vazio com seus não sensoriais objetos.

Existe necessidade de autofundamentação na "situação epistêmica", pois esta tem sido ainda irreconhecível característica da condição do observador que precisa manter e/ou expandir fontes do que apropriar no exterior de si mesmo. Estas fontes têm de ocorrer como especificidades que 
também lhe são exteriores, enquanto ele próprio se encontra em um ponto, dentre incontáveis outros, na totalidade real. Assim, o real-concreto de tal apoio perfaz insignificância, assim como conveniência de restar irreconhecível, uma vez que reproduz a extemporaneidade do apoio da pessoa não mais naturalmente autoinsustentável e cujo pensar acabou alheio à sua original inocência no âmago do coletivo natural-mínimo, que lhe constituíra posse até que esta acabasse substituída por propriedades de objetos extrínsecos a sua própria pessoa.

$\mathrm{Na}$ "situação hipostêmica" existe necessidade de desalienação, pois ela tem sito característica da condição real-concreta, também ainda irreconhecível, de inequívoco produtor que, enquanto tal, não tem tido como observá-la. Trata-se de condição que permanece usurpada, por ser imprescindível ao atendimento da extemporânea autoinsustentabilidade de adultos excessivamente apropriadores. Já esse atendimento presume atividades, e/ou resultados destas, a terem de ocorrer, em crescente parte, no exterior da propriedade da pertinente fonte, ou seja, forçosamente gratuitas.

Cumpre, então, ultrapassar o que permanece ainda irreconhecível e a perfazer ambas aquelas "situações", alcançando-se uma síntese que passe a ser denominada de "ínfero-referencial" (situação alterina à "epistêmica" e à "hipostêmica", ocorrendo por entre assumir opcionalmente gerar "gratuidade", ou então, criar o absurdo da propriedade enquanto matriz de incontavelmente mais problemas do que soluções $\left.{ }^{1}\right)$. Trata-se

1 Conforme Bergamo (2007, p. 139-140). Trata-se de argumento que influenciou a busca de saída para a problemática em que a docência se vê imobilizada por uma espécie de "camisa de força". Só a gratuidade lhe permite mover-se. (Assunto acima já abordado, em II, D). A criação de incontavelmente mais problemas do que soluções será discutida mais à frente (III, B, 1). 
de síntese que tende a coincidir com "situação diastêmica", básica e inarredável, e que teria sido buscada por Sócrates ${ }^{2}$.

Absurdo criado vem a ser uma sociabilidade eivada de injustificações, ou seja, plena de desigualdades políticas, disparidades econômicas e desníveis de acesso à tecno-ciência, as quais têm ocorrido entre si inseparáveis. Sintoma elucidativo dessa sociabilidade reside em se ter que sempre mais "pagar para produzir", em vez do que é divinamente natural ou naturalmente divino, ou seja, obter resultados, os melhores e mais amplamente possíveis, compensando o esforço de intercambiar com a natureza, direta e organicamente.

Por sua vez, a opcional geração da "gratuidade" ainda permanece represada, ou seja, resta apenas tencional e potencial. Esta geração se explica e é justificada na relação entre pessoa e coletividade, à medida que esta última, ao contrário da primeira, caracteriza-se por não se constituir nem se manter por si mesma, mas ambas, e concomitantemente, são imprescindíveis à reprodução da espécie. Não há como subsistir suficiência de coletividade, sem um excesso de atividades e/ou de resultados destas, excesso este a ocorrer, necessária e ainda insuficientemente, fora da propriedade particular-pessoal. Tal ocorrência há de constituir antídoto à fonte do desejo de acumular propriedades, fonte que, de forma recorrente e predizível, há de renascer, como o mito da "fênix", das cinzas das revoluções contra a mera objetividade do alcance privado da propriedade.

Em síntese, "ínfero-referencial” há de sugerir alteridade de relações humanas, cujo paradigma resida nos teores da relação entre prole ainda autoinsustentável e quem, direta ou

2 Segundo Aristóteles (1984, p. 24), apenas Sócrates abordara "coisas morais, e de nenhum modo do conjunto da natureza", abrindo caminho para Platão o fazer em "outras realidades e não nalguns sensíveis". 
indiretamente, a sustenta. Com efeito, esses teores perfazem relações interpessoais, cuja extrapolação para reais-concretos mais complexos tem sido abortada por falta de mediação pedagogicamente dialética entre "posse e despossessão do coletivo natural-mínimo".

Assim, cabe ao menos hipotetizar que o objeto da pedagogia tem sido uma omissão - um vazio, uma vacuidade ou um abismo. Por sua vez, a condição desse objeto faculta-lhe acabar preenchido, ocupado e colonizado por ideologias, a partir daquelas a respeito de processos humanizadores. Alterinamente, presença de mediação pedagogicamente dialética há de significar objeto preventivo de vitimação a ideologizações, a começar pelo recurso metódico a uma especificidade dialética que perfaça radical real-concretude humanizadora. Porém, antes de recorrer a essa especificidade dialética, cumpre apresentar os fundamentos aos quais foi possível chegar, à conta das considerações até este ponto desenvolvidas a respeito do ensino superior, à base da pertinente prática social, assim como da problematização quanto à qualidade e à cientificidade de tal ensino.

\section{B. "Historização" enquanto "paradigma da insustentabilidade coletiva"}

\section{Absurdidade em construção}

A história, enquanto processo propriamente cultural-civilizatório, desdobra-se em dois mais peculiares e continuados desfechos que têm sido, insistentemente, referenciados por oriental e ocidental. É-lhes comum, todavia, uma cultura a se autoequivocar sobre o que seja produzir, autoequivocação que lhes perfaz um "substrato-chave" mais visível nos contrafortes das estáveis instituições extremo-orientais, porém 
recorrentemente escondido nos bastidores das inconstantes organizações ocidentais. Estas, por sua vez, são assumidas tais como acabaram interpretadas pelo sociólogo Max Weber (1983, 1-15), na introdução de sua ainda inconteste tese sobre alternativa de espírito capitalista. Resta implícito que, sopesadas as correspondentes ideologias, as instituições ocidentais têm assumido um vezo antes agressor do que defensor da imprescindibilidade de um produzir nunca diferenciado de apropriar, o que (ainda) lhes faculta se beneficiarem de uma alegada superioridade de processo cultural-civilizatório.

No Oriente, o que se caracteriza como propriamente institucional tem a ver com a imprescindibilidade de produzir em reciprocidade de coerência com intercâmbio orgânico com a natureza - livre e humana - e com a defesa das condições de prevalecer conformidade com o caráter assim imprescindível de a produção se realizar.

No Ocidente, institucionalidade tem sido resposta socialmente superestruturada por força de um problema culturalmente recriado e bem determinado, o qual diz respeito à inarredável e escondida interessença que motiva a conquista e a preservação do poder. Trata-se de interessença que se traduz na imprescindibilidade artificial-cultural de garantir, a todo custo e previamente, o atendimento das necessidades básicas, inclusas aquelas da espécie, as quais, em si mesmas e a rigor, têm sido avalores, ou mesmo antivalores. A rigor, o que acaba valorado é o pertinente atendimento, em si mesmo, bem como na imediata e mais adequada prontidão dos requeridos meios. Todavia, tal valoração vem acontecendo de forma peculiarmente apropriativa do "intercâmbio material-comunicativo" entre pessoas, entre estas e as organizações e entre as próprias organizações. Por sua vez, essa forma apropriativa vem ocorrendo à conta de autoequivocação, quanto a produzir, devida 
a pessoas e prepostos das organizações. Já aquele intercâmbio, apesar de imprescindível à expansão da produtividade, sempre se encontrou inserido em uma cultura negadora da "gratuidade" da perspectiva de quem a gera, a começar por aquela da natureza livre e, cabalmente, também da humana.

Cumpre, então e ao menos, hipotetizar sobre três fundamentos dessa cultura peculiarmente ocidental: (a) ao negar a natural "gratuidade" humana, os seguidores dessa cultura desvelam seu vezo inercialmente reprodutivo da "posse do coletivo natural-mínimo", o que tem ocorrido por além do período de natural autoinsustentabilidade da pessoa que, na espontaneidade dessa posse, conta com outrem para se sustentar, sob pena de este outrem, alternativamente, sequer ter como subsistir; (b) ao longo da história individual e desavisadamente, equivocar-se quanto a produzir vem desandando em um esfalfar-se racional-operativo, pelo qual se busca compensar, à base de propriedades exteriores à própria pessoa, a perda do originário vínculo de parentesco; e, (c) ao contrário do que se presume como algo imemorialmente ocorrido no passado da espécie humana, "o primeiro ato histórico do homem"3 sempre houve de coincidir com aquele de negar, sem disto sequer se dar conta e na história de cada uma e de todas as pessoas, a "gratuidade" que é inerente à natureza livre

3 A expressão "o primeiro ato histórico" do homem foi suprimida por Marx e Engels do manuscrito sobre a "Crítica à Ideologia Alemã", ao longo da revisão para efeito de vir a ser publicado. Todavia, foram apresentadas, segundo Manacorda $(2007,61)$ "não sem certa ironia", circunstâncias - o quanto possível verossímeis, conforme se presume - em que esse ato poderia ter acontecido, para que se coadunassem com certas posturas dos ideólogos alemães, os futuros e mais prováveis leitores. Nesta perspectiva, ao mesmo tempo irônica e verossímil, cabem ser examinadas aquelas circunstâncias, ao se ter em vista estabelecer distinção entre indivíduos humanos e espécimes animais. É que, segundo a denominação proscrita, o que caracterizaria o alcance humano desses indivíduos "não é o (ato) de pensarem, mas o de começarem a produzir os seus meios de vida". 
e às próprias pessoas, criando-se, por uma parte, escassez de espaço vital, inclusive para o poder coincidente com tal negação e, de outra parte, a necessidade cultural de a obtenção de meios de atender as outras e naturais necessidades ser reduzida ao secreto significado de servir tão somente de pedestal aos poderosos.

A “criação de escassez" de espaço vital tem coincidido com uma sociabilidade cujo fulcro vem sendo a interdependência entre o próprio criador e quem, inequivocamente, o sustenta. Trata-se de fenômeno que usurpa o sentido do coletivo natural-mínimo, substituindo-o por relações sociais a se desvelarem peculiarmente em ambiência citadina. Por sua vez, essas relações se processam de modo sincrônico-topocêntrico, tirante à circunstância que faculta conceituar espaço em física, vale dizer, não houvesse efetivos ou potenciais choques entre unidades de matéria, tal conceituação seria impensável.

O método seguido pela "criação de escassez" de espaço vital coincide com a dinâmica que é própria do açambarcar o que é imprescindível ao atendimento das necessidades básicas, ou seja, das fontes dos meios de vida. A ambiência citadina se "historiza" à base desse açambarcamento, porque dela são projetados tentáculos que servem para impingir e carrear excedentes gratuitamente gerados pela natureza livre, sem que, a esta, seja devolvido um equivalente para sua autorreprodução. À medida que esses excedentes acabem escassos, torna-se necessário promovê-los mediante direta interação com as correspondentes fontes naturais. Para tanto, e até a Revolução Industrial, recorreu-se à exploração da fonte humana de trabalho e, a seguir, à acentuada instrumentalização desta fonte que, por seu turno, vê agigantarem-se as circunstâncias em que ela se torna dispensável, de sobra ou em demasia, porque (inconfessadamente) reduzida a estrito e 
descartável meio de produção. Trata-se de tendência sistêmica e que se processa à base de um impingido reducionismo. É no complicado bojo desse processo que acabam depredados os ainda irreconhecíveis potenciais de "gratuidade" de fonte humana e a efetiva "gratuidade" da natureza livre. Para tanto, ambas - a efetiva e as potenciais - acabam subsumidas sob a ideologia de uma produtividade que, a princípio, seria ilimitadamente intensificável e abrangente.

No alcance sistêmico dessa tendência, impingir geração de excedentes de produção fora da propriedade das respectivas fontes tem sido objetivo ocultamente efetivado e/ou desejado. Uma vez efetivado, este objetivo se concretiza como propriedades exteriores às pessoas dos próprios impingidores. Se desejado, implica em existência imaterial de pertinentes objetos, imaterialidade que há de incidir em infinitude para corresponder à ilimitação que é própria da autoentrega humana à incontinência apropriativa.

Essa imaterialidade sempre deteve "modo de existir "privacional"” (vazio, vacual e não sensorial). Já as propriedades, enquanto reais-concretos perceptíveis, têm "modo de existir "presencial"' (plenista, material e sensorial), caracterizando-se por subsistirem inclusivas de um ou poucos detentores efetivos e excludentes de todos os detentores potenciais que, por isso mesmo, se expõem a tão somente desejá-las.

Ao longo da "historização" da ambiência urbana, desde os refúgios mais primitivos até chegar às metrópoles modernas, a apropriação tem desandado na propriedade e a proliferação desta em incontavelmente mais problemas do que soluções. Tal evolver cultural-civilizatório tem como ser aquilatado, inclusive à base de ciências positivas. Para tanto, há como entender por solução o mero e direto dispor de meios de vida, interagindo tão somente com a natureza livre, apesar de esta 
interação, à conta de requerido desconforto, ter sido, de modo recorrente e predizível, o mais significativo dos problemas em questão. Por sua vez, problema acaba definível também pela necessidade de acessar utilidades no âmbito de propriedades alheias, implicando contratos, além de defesa contra a realização de incontidos desejos de açambarcadores. Assim, haveria tantas soluções quantas fossem as propriedades, mesmo que a proliferação destas acabe por reduzir a possibilidade de constituírem soluções. Entretanto, hão de existir tantos problemas quantos forem as providências defensivas e os contratos para acessar propriedades contíguas e, sobretudo, interpostas entre a própria e as demais. Então, duas propriedades implicariam duas soluções e possivelmente dois problemas. Três delas, significariam três soluções e meia dúzia de possíveis problemas, à conta de que os três precisariam acessar as propriedades de outros dois. A seguir, doze ou vinte possíveis problemas presumiriam quatro ou cinco propriedades, respectivamente. A onipresença da propriedade exigiu o "intercâmbio materialcomunicativo". Mas, até mesmo este intercâmbio e, a seguir, a funcional mediação do dinheiro, ambos acabaram também apropriados. Com isto, passou a ser demandado que a científico-tecnologia dê conta da incomensurabilidade e da complicação dos problemas. Cabalmente, até mesmo a científico-tecnologia está a ser apropriada, perfazendo um desafio que faz o gênio humano adentrar uma fronteira em suas potencialidades.

$\mathrm{Na}$ atualidade, a cibernética, imbricada em instrumentos produtivos, tende a ser tida como promessa de soluções. Entretanto, ela ocorre concebida de forma alheia às implicações da dinâmica apropriativa, o que não a isenta de ilusionismo. 
Trata-se de apontar como as relações sociais, a começar por aquelas de produção, perfazem circunstâncias em que as pessoas têm de sobrar, vale dizer, sentirem-se descartáveis ou constantemente ameaçadas de violência, desde a competitiva até aquela da iminência de exclusão.

O fulcro da análise a ser feita reside no preterir (marginalizar, informalizar e sócio-subjetivar) a relevância humano-científica da obtenção e da destinação dos excedentes que sustentam a reprodução da espécie e das condições objetivas de o próprio coletivo se realizar. Tais excedentes passam a ter que competir com o mero custeio da imprescindível participação no processo produtivo. Já esta participação, por se encontrar exposta à dinâmica apropriativa, tem sido excludente critério de acesso aos resultados desse mesmo processo. Assim, para abordar o fulcro em apreço, cabe recorrer ao método do qual Marx (2003, 246-258) se valeu para analisar a economia política de seu contexto histórico, restringindo-se a análise, entretanto, ao real-concreto da formação dos preços finais dos bens e serviços. Nesta formação, chega-se a apenas duas categorias simples: (a) o que é vendido sem ter sido comprado - mais-valia definida por Marx em "O Capital” (1984, p. 246), diversamente da conceituação contida em "Salário, preço e lucro" (1983, p. 62-65); e, (b) o que é comprado e também vendido, ou seja, custos aquilatados à base de preços que, por sua vez, compreendem outros, em uma cadeia retroativa, cujo ponto de partida é a remuneração de estrita propriedade, cabalmente aquela de direitos sobre resultados da produção, os quais perfazem itens dessa mesma mais-valia.

Os prepostos mais decisivos para a (re)-produção desse real-concreto são aqueles que operam nos labirintos do Estado e do Mercado. Nos labirintos do Estado, vendem-se tributos e naqueles do Mercado retornos privados (líquidos de 
tributos), ambos - tributos e retornos - sem terem sido previamente comprados. Entretanto, desde a captura do Estado pela revolução burguesa, tem acontecido que a expansão dos tributos dependa da perspectiva de expansão dos retornos privados (líquidos de tributos), o que traduz uma espécie de "pacto tácito e, às avessas, entre menos desiguais" (às avessas, porque, até a sustentabilidade da competição e dos conflitos entre os dois partícipes há de resultar em vantagens adicionais para ambos e, à margem, ônus para as fontes de excedentes gerados de forma forçosamente gratuita). Inserção dessas e de outras vantagens e ônus, nos preços dos meios de trabalho, implica em estratégia sistematicamente efetiva para condicionar a destinação das remunerações pessoais, na perspectiva de os beneficiários destas remunerações terem de pagar, sempre mais, para tão só produzirem. Paralelamente, desalienação dos trabalhadores tem desandado em luta contra a exploração deles próprios. Trabalhadores improdutivos também se valem dessa luta para preservarem e/ou expandirem poder aquisitivo das próprias remunerações. Além destes últimos, chegam a emergir nada mais do que lutadores a reivindicarem remunerações cuja contrapartida em termos de responsabilidades tende a se restringir a meras mobilizações sociais em defesa dos próprios direitos. Ao final, desalienação tende a se caracterizar como questionamento da propriedade em si mesma, mas, paradoxal e acentuadamente, volta-se para recriá-la sob a forma de novos direitos sobre os resultados da produção. Ora, nada resulta mais custosamente conflituoso do que a prática de questionamento e de recriação de direitos, urgindo, então, estimular retornos privados para expandir tributos, o que demanda acréscimos na produtividade física (pressão por avanços científico-tecnológicos) e inchaço do trabalho improdutivo (aumento das contraprestações). Cabalmente, o atendimento dessa demanda realimenta a tendência em alcance propriamente sistêmico. 
Em síntese ou em um sempre mais visível desfecho, os excedentes para a reprodução da espécie tendem a acabar competindo com o custeamento privado de participar do processo produtivo, o que passa a ocorrer em "soma zero" (o aumento desse custeamento há de coincidir com diminuição daqueles excedentes ou vice-versa). Em desfecho, tende a se consumar a absurdidade, ou seja, a situação em que os seres humanos se encontrem de sobra, supérfluos ou descartáveis. A escassez de espaço vital favorece a busca de ilusões e impede que estas sejam abandonadas, recorrendo-se ao fetiche da igualdade de oportunidades para consolidar fé profana na tríade constituída por política, epistemologia e economia como inescapável matriz das ciências que passam a substituir o império e o capital na função de explicar e perpetuar as injustificações. Em contraponto, desalienação a respeito dessa fé tende a ser acentuadamente disfuncional ao pacto tácito entre Estado \& Mercado enquanto esconderijo da interessença dos apropriadores do sentido do "intercâmbio material-comunicativo".

\section{Perspectiva de "crise da historização" e seus dois horizontes mais visíveis}

A positividade científica da análise e da síntese, logo acima apresentadas, faculta anunciar uma "crise da historização" que vem sendo endógena aos cinzentos bastidores do processo cultural-civilizatório do Ocidente e em vias de se tornar global.

Essa "historização" tem enveredado por recorrentes e previsíveis descaminhos, dada a circunstância de se resumir ao acúmulo de eventos que decorrem de o ser humano precisar fazer guerra contra tudo, para não guerrear contra si mesmo ou contra a sua própria interessença, ainda que esta e ele próprio se evidenciem demolidores do sentido também coletivo da sustentabilidade. 
Reorientações em tais descaminhos têm ocorrido, em largos traços históricos e em concomitância com mudanças coletivo-sustentatórias a derivarem de "intercâmbio material-comunicativo". Presume-se que este intercâmbio foi deflagrado no Oriente Médio e ao longo das costas do Mediterâneo Oriental (territórios que evocam os nomes de Suméria, Babilônia, Egito, Fenícia, Creta, Anatólia, Hélade, Magna Grécia e Cartago). Em peculiar momento da afirmação histórica de tal intercâmbio, então sob ameaça de acabar contido por prepostos do Império Persa nos séculos $\mathrm{V}$ e IV a.C., houve notório avanço na concepção de constituições democráticas, o que facultou uma mais complexa convivência humana em cidades-Estado. Foi, também em tal momento, que emergiu a Filosofia, assim como avanços em tecnociência, a exemplo daqueles em instrumentos bélicos e em navegação marítima. Mas, a ideologia imperial acabou por prevalecer também naquelas cidades, tendo, por "vazo comunicante", o que está referenciado em Williams (2000, 47-53) como "lacuna metafísica" em Platão e que cabe atribuir também à Política em Aristóteles ${ }^{4}$ e à apropriação da mensagem de Jesus de Nazaré, inicialmente por helenistas tardios e, a seguir, por políticos devotados à preservação do Império Romano ${ }^{5}$. Todavia, em medievais ambiências monásticas, já isoladas em relação à ideologia profano-imperial, tornou-se

4 Em sua obra intitulada Política, Aristóteles $(2007,145)$ declara que, assim como o todo é superior às partes, um homem extraordinariamente virtuoso deve ser governante vitalício, indo ao encontro da convicção desse filósofo quanto à monarquia coincidir com a melhor forma de governo.

5 Para Russel (1982. II, 34), “o Estado (a corte imperial romana) era fraco, incompetente, governado por homens sem princípio, que procuravam defender apenas seus próprios interesses, sem qualquer política que fosse além de expedientes do momento", ao contrário do que ocorria na Igreja que era dirigida por homens "prontos para sacrificar tudo no interesse dela" e, por isso, veio a ser vitoriosa ao longo de todo um milênio subsequente. 
enfim possível conciliar riqueza com até mesmo ascese de inspiração religiosa que, apriormente, sempre a rejeitara:

O paradoxo de todo ascetismo racional, que de forma idêntica fez tropeçar os monges de todas as épocas, está em que o próprio ascetismo racional criou a riqueza mesma que rejeitava (Weber, 1982, p. 380-381).

Anteriormente a essa observação de Weber, Marx já apreciara mudanças materiais possibilitadas, em seu entender, pelo capitalismo de seu tempo. Entretanto, em uma espécie de gesto mecânico, subsumido à sua (desde então até necessária) anatemização da mercadoria, o mesmo Marx jogaria fora com a "sujeira da água do primeiro banho" o renascimento do "intercâmbio material-comunicativo" junto com o avanço da modernidade, gesto que Habermas relativizou, porém não resolveu, ao eleger-lhe o alcance comunicativo e, à conta de redução a instrumental, ao preterir-lhe a materialidade.

Essa atitude de Habermas teria como compor resposta a uma crise na apropriação da base material-planetária do intercâmbio, nos bastidores das Guerras Mundiais, do Holocausto e do bombardeio de Hiroshima e Nagasaki. Por hipotético que tal ajuizamento ainda precise ser assumido, cumpre explicitá-lo à luz de certa repetição, no advento e no avanço da modernidade, do que ocorreu ao longo do ocaso da Antiguidade Clássica. Trata-se de ajuizamento que cabe ao saber acadêmico pesquisar-lhe a fundamentalidade e o assumir, desde que se tornaram inusitadamente conservadoras as circunstâncias em que emergiram o pós-modernismo, o pósestruturalismo e o pós-industrialismo nos atuais horizontes da cultura e da civilização. Além disso, urge que esse saber se reconheça ainda insuficiente para prevenir as injustificações que hão de conduzir a novos descaminhos. 
Em tal perspectiva, resta ao menos admissível que crise ainda detenha significado analógico àquele que remonta à medicina de Hipócrates (460-377 a.C) e que "indicava a transformação decisiva que ocorre no ponto culminante de uma doença e orienta seu curso em sentido favorável ou não" (ABBAGNANO, 2007, p. 259). Esse sentido analógico de crise tem respondido ao alcance miticamente estável das instituições, ou seja, à crença na ausência "de conflitos políticos e sociais insolúveis, de lutas ideológicas, de antagonismos filosóficos e religiosos, a testemunharem a fundamental incerteza ou ambiguidade dos valores da época" (p. 259).

Em desfecho de sua (assim admissível) crise, a "historização" há de se bifurcar em dois horizontes cabalmente mais visíveis: (a) continuidade da extemporânea "posse do coletivo" na esfera da subjetividade, ou seja, na permanência de autoentrega à absurdidade em construção que, por sua vez, também continuará a ser objetivada enquanto artifício a decorrer do seguimento da racionalidade moderna; é seguimento que tem sido alheio ao discernimento entre apropriar e produzir, apesar de este mesmo discernimento adentrar uma espécie de promessa de reverter o vezo fragmentarista do conhecimento, vezo que foi deflagrado pelo enciclopedismo e que se encontra em vias de ser globalizado pela (residual-imperial) insistência de transformar em hegemônicas, para não dizer excludentes, as regras cientificizantes do método; e, (b) admissibilidade de que haja "despossessão do coletivo", na perspectiva da "historicização" da práxis de anuir, em alcance propriamente transpessoal, ao sentido da flexível vital-fertilidade do produzir inequívoco e opcionalmente empreendido - é o que cumpre desde já denominar como "humanização 'crítico-teórica”, vislumbrando-se ultrapassar, em alcance genuinamente acadêmico, insuficiência crítica de teorias em geral. 
Neste horizonte de "historicização", cumpre questionar as circunstâncias vigentes, mediante proposição de alteridade de saída ao menos no âmbito das humanidades. Trata-se de saída pela qual a referência marxista do modo de produção há de acabar substituída por inequivocação quanto a produzir, por aquém do que vem sendo proposto à base de correção do discurso político e de radicalidade normativa. (Tal alteridade de saída tem a ver com questões ainda inadmissíveis cujas sínteses são apresentadas logo a seguir).

\section{Questões alternativamente inadmissíveis}

Subsistem (não escassos) reais-concretos que ainda não têm tido oportunidade de se tornarem fundamento de correspondentes objetos de saber. Nesta altura das questões que devem preceder à abordagem da especificidade dialética, cumpre ter em vista, dentre esses reais-concretos, os três tópicos que se seguem.

Em primeiro e principal plano, emerge a questão de que o significado do que seja propriamente produzir tenha como ser inferível, à base da "relação entre prole e quem, direta ou indiretamente, a sustenta". O real-concreto a que corresponde essa relação sempre houve de coincidir com a sustentabilidade do coletivo natural-mínimo, assim como de perfazer uma referência de (ainda potencial) "historicização", cujo substrato-chave há de incidir em despossessão, ético-educacionalmente mediada, de coletivos progressivamente mais complexos. A dialética dessa despossessão adentraria radicalidade, por incidir em inalienável "real-concreto humanizador" e, por isso, seria também antisseletivista. Ademais, cumpre admitir que a reprodução de elites tem sido radicalmente incompatível com democracia. E, mesmo que 
se tratasse de uma elite acatada como virtuosa, ela teria que se caracterizar por assumir reciprocidade de coerência com essa mesma incompatibilidade.

Racionalidade com relação a fins e a valores é outra das questões em apreço, pela circunstância de se restringir apenas a processos e a pertinentes desfechos. É que essa racionalidade não se volta para sequer a eventualidade de lhe subsistirem pontos cegos ou costas, cuja percepção e interpretação incidam no desvelar-se da razão a si mesma. Há sintomas dessa incidência, dentre os quais destacam-se duas subquestões: (a) aquela da "situação epistêmica", acima já descrita e sumariável como sobrepor-se a diferenças como se fossem identidades (especificidade disto ou daquilo não deixa de incidir na diferença que é própria de uma totalidade), ou então, calar sobre diferenças pertinentes a resultados que presumem funções; e, (b) "criação de escassez", igualmente já exposta e sintetizável como imperceptível acumulação de objetos de desejo ainda irrealizado ou irrealizável, a ocorrer em alcance sincrônicotopocêntrico, ou seja, como matriz de contraditórios aos quais correspondem contradições.

E, já adentrando o limiar de especificidade dialética, há a questão pouco ou nada acessível à própria reflexão e que precisa vir referenciada por "identidade a toda prova". Trata-se da identidade que só é própria à imaterial infinitude em que resulta a imperceptível acumulação de objetos de desejos irrealizáveis ou a ainda serem realizados, vale dizer, ao "modo de existir "privacional"” de tal acumulação, ao qual se chega por força do inescapável ponto de partida da produção intelectual. Tal identidade - primordial produto em dialética - perfaz requisito para a fundamentação do método e da formalidade lógica. Por força de tal princípio ou ponto de partida, é este modo de existir que, em oposição àquele perceptível 
da propriedade, permite deflagrar a determinação da especificidade dialética, ou seja, a fundamentalidade de toda a investigação ora em processo.

\section{Especificidade dialética}

\section{1. "Forma por entre opostos" inerente ao real- concreto da dinâmica do desejo}

Não tem feito sentido algum "o homem" nascer e viver tendo necessidades, sobremaneira as básicas e as da própria espécie, de tal forma que ser livre coincide com o atendimento da (anteriormente mencionada) necessidade histórico-culturalmente criada de avalorar ou mesmo antivalorar o alcance vital-básico de certas necessidades. Esse atendimento significa prevenir inserção em relações de produção, as quais guardem reciprocidade de coerência com intercâmbio orgânico com a natureza. Adentra-se, então, à socrático-platônica dinâmica do desejo, cujo real-concreto se processa dialeticamente. Tal adentramento é logo a seguir apresentado, à base de concepções do que há de perfazer essa dinâmica.

De início, concebe-se um "miolo" de uma totalidade, o qual perfaz, realisticamente, uma forma de existir por entre dois modos. Um destes modos é epistemicamente perceptível, enquanto o outro é ocultamente fenomênico. Ambos se opõem, à base dessa mesma forma e enquanto inescapáveis componentes da própria dinâmica do desejo. Há, então, a condição "presencial" da propriedade - esta, enquanto objetos perceptíveis ou materialmente aparenciais. Trata-se de condição que desperta os sentidos e faz repousar o desejo. Também há a condição "privacional" da falta de objetos, falta esta a incidir em necessidade criada que, de per si, é imperceptível 
e imaterial. Por sua vez, esta condição contém e delimita os sentidos, o que atiça o desejo a ponto de revesti-lo de ansiedade. Então, aquela forma tem como ser inferida em alcance tão existencial quanto ambos esses modos. Assim, a totalidade percepção-inferência-interpretação incide em efetiva produção cultural, inclusive em horizontes da síntese dos opostos na proposta marxiana de inverter a anterior concepção idealista da dialética em Hegel.

Com efeito, à luz da história filosófica das conceituações da dialética em Abbagnano (2007, p. 315-22), chega-se a tal forma de existir, contando-se com procedimentos cuja aplicabilidade serve de apoio para avançar na busca de qualidade em produção cultural. Para tanto, emergem três momentos: (a) coloca-se algo "abstrato e limitado" (aponta-se uma tese, a exemplo daquela de que, na modernidade, "espírito do capitalismo" seja significativo teor do "assunto socrático-platônico" que é pertinente à dinâmica do desejo e, enquanto tal, perfaz objeto abstrato-intelectualmente disputacional ou erístico); trata-se da ilimitável imaterialidade da "escassez criada" a se fundamentar na oposição à limitada realidade da propriedade; (b) suprima-se essa limitada realidade - a propriedade - e haverá inserção em determinado oposto (antítese); trata-se da inserção na estritamente imaterial existencialidade da "escassez criada" (inserção à qual os despossuídos têm tido que se sujeitar desde tempos imemoriais e que precisaria ser vivenciada pelos capitalistas após a marxiana despossessão das fontes objetivas dos meios de vida); e, (c) resulta, daquele fundamentar-se na oposição e desta inserção na antítese, que a imaterial realidade (dos objetos de desejos irrealizáveis ou ainda não realizados) tem tido, por si mesma, como coincidir com a "situação epistêmica", esta enquanto circunstância em que é facultado perceber-inferir-interpretar tudo o que apraz a um apropriador; por isso, a "situação diastêmica" há 
de coincidir com aquela que é imprescindível para se chegar a autoconhecimento (síntese dos opostos, inferencialmente por entre modos de existir e como qualidade na produção cultural de determinado "real-concreto a se humanizar").

Contando-se com apoio assim inferencial, torna-se possível ao menos aventar uma "forma de existir por entre opostos" que subsista tão radicalmente real-concreta quanto o fazem o "modo de existir "presencial"" e o "modo de existir "privacional", além de os três - ambos os modos e aquela forma - serem inseparáveis por inteirarem um todo abstrato-representado que corresponde a um único real-concreto. Porém, a forma se tornará assim (auto)-inferencial tão somente na "situação diastêmica" (na interioridade desse todo). Em sua realidade, trata-se de forma a refletir co-fundamento de um real-concreto e a se inferir tão somente na sua coincidência com este mesmo co-fundamento.

À base desse todo assim abstrato-representado, autoconhecimento há de coincidir com despossessão de coletivos, ou seja, inverte-se a condição da sustentação individual, antes provinda do coletivo natural-mínimo e, desde agora, tendo que ser entendida como imprescindível, além de procedente tão só da pessoa, da parte ou do componente do coletivo. Trata-se de inversão que só ocorre mediada por inequivocação quanto a produzir autoconhecimento, mesmo que este produzir tenha que fazer sua história à margem dos vigentes modos de produção que, por seu turno, se caracterizam por subsistir inseridos na ainda inescapável dinâmica do desejo. Ademais, produzir é prática carente de reflexão por implicar limites ao apropriar exteriormente às partes e, por reciprocidade de coerência, interiormente a esta ou àquela totalidade.

A forma assim situada há de incidir na própria dialética como qualidade procedimental, instaurando-se uma tríade 
metódica que se constitui de: (a) constatação - à conta dos sentidos, inclusive mediante instrumentos - do "modo de existir "presencial"" dos reais-concretos que são abstraídos no processo de conhecimento (fundamentos, realistamente delimitados, que são percebidos e interpretados a partir do miolo da totalidade correspondente à dinâmica do desejo); (b) interpretação do "modo de existir "privacional" por coincidir com ilimitável e real imaterialidade, externamente à propriedade e essencializando o vazio correspondente aos objetos de desejo ainda não realizado e/ou irrealizável; e, (c) "diastemia" como "situação-limite" (fim-começo ou começo-fim), na qual ocorre "incontinuidade-contato" por entre representações correspondentes ao alcance "presencial" e ao alcance "privacional" de um e outro daqueles modos de existir.

Chega-se, assim, à (auto)-inferência da forma enquanto compatível com gnoseogenia, a ser explicitada nos seguintes termos:

"Forma de existir por entre opostos" é aquela que incide em "incontinuidade-contato" por entre dois modos de existir que são entre si cabalmente irredutíveis e que correspondem, de uma perspectiva, ao "presencial" (aquele que desperta os sentidos de quem observa e faz repousar-lhe o desejo) e, de outra, ao "privacional" (aquele que anula os sentidos e atiça o desejo). "Incontinuidade-contato" coincide, em alcance conceitual, com a condição de fim-começo ou começo-fim das delimitações, quer externamente ao (modo de existir) "presencial", quer internamente ao "privacional". Essa coincidência vem a ser "nascimento-morte ou morte-nascimento" dos (entre si irredutíveis) opostos e se traduz na especificidade da forma que, por isto, se desvela tão concretamente real quanto os próprios opostos e, ao mesmo tempo e lugar, coincide com ultrapassagem do contraditório. 


\section{2. "Forma mediativo-configurativa" por entre os sentidos da exurgência das necessidades vital-básicas e do mover-se das funções que as atendem}

Dispondo da conceituação referente à "forma de existir por entre opostos", há como admitir que o "modo de existir "privacional"" esteja a usurpar a cognoscibilidade da condição "ausencial" como ocorre a teleconvergência entre os sentidos do exsurgir das necessidades vital-básicas, inclusas as de reprodução da espécie, e do mover-se das funções que se voltam para atendê-las.

Com efeito, houve de acabar presumido, ou mesmo subsumido, que essa teleconvergência adentre uma tal insignificância que sequer perfaça objeto de estudo. É que o modo de ser das necessidades, por si mesmas, não é diretamente cognoscível (não é objeto imediato de percepção e abstração), o que, entretanto, não impede que se admita sentido, contrário àquele das necessidades, ao modo de ser das funções, também por si mesmas. Assim, por conta desta contrariedade e de que o atendimento das necessidades vital-básicas tem de provir do exterior e se destinar ao interior da pessoa, resta supérfluo ser incognoscível a teleconvergência dos sentidos de ambos esses modos de ser.

As cruciais e entre si irredutíveis realidades dos sentidos de ambos esses modos de ser têm efetivamente teleconvergido, o que faculta inferir "incontinuidade-contato" por entre uma e outra das realidades em questão. Para tanto, incide-se em três momentos: (a) há o sentido do exsurgir das necessidades, o qual, não só procede do interior para a aparência ou para a exterioridade da pessoa, como também coincide com o inevitável e contínuo esvaecer-se das energias, tanto 
conjunturalmente (origem da fome, por exemplo), quanto estruturalmente (origem do envelhecimento); (b) há o sentido do projetar-se das funções, o qual advém do exterior e se orienta para a interioridade da pessoa, coincidindo com o atendimento das necessidades, desde as básicas e as da espécie, até aquelas que derivam das anteriores e que emergem em reciprocidade de coerência com intercâmbio orgânico com a natureza; e, (c) há "incontinuidade-contato" por entre ambos esses sentidos, a qual intervém, como "forma de ser "interflexa", e o faz à base de reciprocidade de pertinência para explicar e de coerência para justificar a individualidade humana, em alcance complexamente relacional entre a pessoa e o coletivo.

Por sua vez, tal reciprocidade faculta intuir o significado do que deva perfazer "razão dialética" que, então, há de coincidir com "situação interflexa" da forma de ser da "incontinuidade-contato" por entre sentidos que guardam reciprocidade de coerência e de pertinência quanto à relação entre coletividade e singularidade humanas. Assim, "incontinuidade-contato" por entre diferenças, por entre identidades, ou ainda por entre uma(s) e outra(s), coincide com o vértice que é interflexo à individualidade e no qual começam e terminam, ou vice-versa, o sentido de uma comunhão de necessidades a se impor como atratividade do que as atende (congraçamento, sociabilidade) e o sentido de uma conexão de funções que correspondem a tal imposição (ética, responsabilidade). Esse vértice se evidencia por entre o que é necessário e o que é funcional, possibilitando integridade da individuação da pessoa e da coletividade, ambas a se objetivarem como realizações. 


\section{Avanço coerente com a história da dialética por entre opostos}

A complicação que caracteriza a abordagem desta subunidade responde ao enigma com que um ente humano pensante se depara ao encarar o artifício histórico-cultural que lhe é presumido ao se abster de produzir a própria existência em reciprocidade de coerência e pertinência quanto a intercambiar diretamente com a natureza. Resta explicável, conquanto nunca justificado, que tal complicação não seja enfrentada. É que exercício de poder dispensa o esforço próprio de discernir os sentidos do exsurgir das necessidades vital-básicas e do projetar-se das funções de as atender. Inversamente, entre apenas desejosos de tal dispensa, tem subsistido excesso de esforço no padecer tal atendimento e, por isso, estes desejosos têm estado de antemão impedidos, sob pena de exclusão até fatal, de se dedicarem a percorrer o labirinto dos pertinentes raciocínios. Assim, impasse se torna óbvio, dada a ausência de contestação enquanto prerrogativa da propriedade do poder.

O "modo de existir "privacional"” da escassez imaterialmente criada tem sido facilmente ideologizável como substituto do "modo de ser 'ausencial"" e, por isto, houve de restar usurpante da "forma de ser "interflexa", o que faz a "historicidade" de discernir entre apropriação e produção estar imiscuída com a "historiedade" de criar a condição imaterial da escassez. Assim, cumpre que se assuma "dialeticidade da razão" (pensar modos de existir em oposição a modos de ser), a qual previna ausência de "incontinuidadecontato" como via de ultrapassagem da separação entre duas determinadas oposições: (a) por entre a diferença do "modo de existir "presencial"" das propriedades e a identidade a toda prova do "modo de existir "privacional"" dos objetos de desejo 
irrealizável e/ou ainda irrealizado; e, (b) por entre os sentidos como exsurgem as necessidades e como se projetam as funções de as atender.

O processar-se desse pensar - por entre existir e ser - há de coincidir com um estrito arrazoar dialeticamente. Já este arrazoar tem sido represado, inclusive desde o tempo em que, segundo Abbagnano (2007, 316-322), a dialética era admitida como assunto propriamente filosófico (método platônico e neoplatônico da divisão) e, notadamente, na modernidade (síntese hegeliana dos opostos e sua inversão marxiana).

Ainda antes de Platão (427-347 a.C.) ter chegado a seu método de dividir a ideia, presumidamente aplicável à (socrática) busca de inequivocação sobre os teores deste ou daquele (acreditado) saber, estava difundida entre pensadores gregos a proposta filosófica de Heráclito (c.540-c.480 a.C.), sobre um excludente e conflituoso princípio a mover os seres humanos e todos os demais entes do mundo. À luz deste peculiar princípio e sob pena de autoentrega, por força deste mesmo princípio, ao estritamente ilusório das meras sensações, não caberia alhear-se às necessidades naturais, a começar pelas básicas e por aquelas da reprodução da própria espécie, cujo atendimento teria tido que impedir o pensar até mesmo filosófico. É que, nesta circunstância, todo pensar teria de se reduzir à mecânica de atender essas mesmas necessidades, sob pena de (auto)-perecimento juntamente com a conflituosa materialidade do mover-se das coisas. A princípio, por tácito que ainda o fosse, Heráclito já explicitava a disputa pelo "alcance culturalmente criado" da necessidade de não padecer o direto atendimento das outras naturais ou materiais, uma vez que a solução desse não padecimento sempre implicou guerra contra tudo, em toda parte e a todo tempo, por não ter como se universalizar outra guerra no âmbito da 
estrita subjetividade humana. Entretanto, resta plenamente admissível que, a exemplo do pensar de Heráclito, ainda não era vislumbrado qualquer sentido em o ser humano nascer e subsistir tendo necessidades assim básicas, apesar de que atendê-las, por além das próprias e das requeridas à autoinsustentabilidade das crianças e dos meios de uso coletivo, teria como justificar a parte (o espécime) em relação à totalidade (à espécie).

Outros filósofos, ao longo desse período em que emergiu a filosofia, buscavam um princípio primordial que explicasse a "physis" (o constituir-se das coisas, também enquanto questão de qualidade). À época, não haveria empecilho de este constituir-se estar a ser por eles concebido como confronto entre "ser" (isento de necessidades ou, talvez, tendo estas sempre e de antemão atendidas) e "não ser" (o próprio modo de ser das necessidades, preterido como vazio, privação, negação, nada enfim). Já o pensar a respeito do "ser" tinha como incidir em resposta à busca de não precisar se submeter ao jugo das próprias necessidades, mediante imemorial recurso ao mais fundante e inequívoco dos significados do que jamais deixou de ser idealizado como poder. Ademais, eram pensadores que preveniam recurso às explicações míticas do mundo ${ }^{6}$, apesar de também buscarem poder (exceto, talvez, Heráclito que teria renunciado a honrarias, dadas as contemporâneas ameaças da expansão persa sobre a cidade herdada de seus antecessores) e presenciavam a influência de legisladores e de mercadores na (re)-apropriação dessa busca, peculiarmente após as cidades-Estado na antiga Grécia terem

6 Cabe ter em conta o que expõe Nunes (1999a, p. 59): “Os amplos campos da filosofia foram sendo constituídos como originários da proeminente experiência cultural e política dos gregos, nos terrenos histórico e político do escravismo dos séculos IV e III a.C., criando, a partir desta realidade, as matrizes que justificariam sua universalização" (Grifo nosso). 
passado a ser hegemônicas ${ }^{7}$. Até então, os deuses, assim como os reis que deles diziam descender, eram tidos como a fonte dos saberes então dominantes e cuja continuidade era objetivo de uma arcaica e conservadora educação (Paideia antiga). Inusitadamente, e por tácito que ainda o estivesse, veio a ser a profano-humanidade de tais filósofos a primordial fonte do pensar e da busca de explicações das coisas ou do mundo.

Com Sócrates (469-399 a.C.), entretanto, passa a ser pensada a impossibilidade de universalizar o atendimento de certas necessidades, embora este filósofo jamais houvesse cogitado a respeito de "escassez criada" de tudo o que as atendesse e cujo imaterial modo de existir sempre se encontrara exposto a ser caracterizado como "privacional" vislumbrar algumas necessidades cujo atendimento era raro, por significar o proceder de uma pessoa sábia, justa e virtuosa, além de previdente, generosa e corajosa. Ao mesmo tempo e em reação à forma sofista de apropriar tal significado, surgiam dúvidas quanto a ser ensinável a prática de virtudes, da ética e do autodomínio.

Com efeito, inequivocação (quanto ao que devia ser entendido por essas e outras qualidades humanas) tornara-se

7 A hegemonia das cidades-Estado tornara-se possível, graças, em parte, à monetarização das trocas de utilidades, a exemplo de artefatos de metais (ouro, prata, cobre, estanho e ferro) e de argila (cerâmicas), tecidos e cereais. Conforme observou Aristóteles (2007, p. 67-70), com essa monetarização tornara-se possível ilimitar a riqueza, o que ele admitia como incompatível com limites naturais da produção de utilidades em geral. Assim, não era de se esperar que, àquela época, fosse declarado por Aristóteles algo a respeito de eventuais influências do enriquecimento de mercadores na destituição dos antigos reis e na investidura dos legisladores no governo das cidades.

8 “(...) como qualquer outro que deseja, deseja o que não está a mão nem consigo, o que não tem, o que não é ele próprio e o de que é carente; tais são mais ou menos as coisas de que há desejo e amor (...)" (PLATÃO, 1975 apud NUNES, 2006, p. 111-112). 
recomendável, para a continuidade da convivência social nas cidades-Estado - estas, à época, caracterizadas por Atenas. Ademais, tinha como incidir em assunto socrático ainda compreendido na dinâmica do desejo, ou seja, a ainda perfazer objeto abstrato-intelectualmente disputacional ou erístico.

Buscava-se inequivocação sobre objetos de presumidos saberes, graças a contribuições de peculiares interlocutores e da notória perícia de Sócrates em os induzir a se depararem com equívocos nos teores que compunham tais objetos. Saberes acabavam aquilatados como opiniões ou meras crenças, mesmo que tidos, até então, como verazes por seus detentores. Em síntese, segundo Nunes (1999a, p. 62), "Sócrates apresentou a conduta moral como aquela que brota do interior do próprio indivíduo e não como mera sujeição coercitiva à lei ou ao Estado, superando a justificação pelo determinismo religioso e a legitimidade estreita da submissão à lei" (Grifo nosso).

A respeito de tal interioridade, caberia formular hipótese sobre inato e primordial potencial a assumir virtude, algo que, inclusive hodiernamente, tem restado liminarmente irreconhecível em favor de aquisições vindas de fora da pessoa - desde mercadorias até favores (tidos por) divinos. É que, já em Platão e sob raciocínios do seu (tido por) interlocutor Sócrates, surgiram propostas de ensinar virtudes, ética e autodomínio, recorrendo-se, para tanto, ao proceder dialético cuja idealidade era traduzida por ascese da alma, conquanto, segundo Williams (2000, p. 54), tenha tido um frustrante desfecho9. Essa ascese, segundo Nunes (2006, p. 134-178),

9 “As oposições radicais da República, entre a realidade eterna e as ilusões do mundo material mutável, não apenas deixaram problemas teórico-filosóficos profundos; elas também frustraram os propósitos éticos de Platão" (Grifo no original). 
iniciava-se como filosofia do amor e devia encerrar-se como amor da filosofia, assumindo um teor retórico.

Platão propõe uma nova retórica, na verdade uma maiêutica, uma elevação da retórica pela reta superação dos sentidos e escansão das sensações, uma verdadeira psicogogia, isto é, uma condução da reflexão pela alma até ideias claras e puras. A esse método de elevação dos sentidos, de subida das sensações às ideias e destas às ideias puras Platão chamou Dialética, para ele a verdadeira e única retórica plausível, a retórica essencialmente filosófica (NUNES, 2006, p. 134. Grifos no original).

A propósito de tal ascese, cumpre destacar a referência platônica de que os governantes, homens ou mulheres, à altura das necessidades da cidade-Estado que ele idealizava na sua obra "A República", precisariam de uma paideia que os tornasse tão virtuosos a ponto de prescindirem da disputa pelo poder e serem capazes de assumir gratuidade nas atividades de governar a cidade.

Se descobrires uma vida melhor do que governar, para os que devem governar, podes conseguir um Estado bem administrado. Pois só nesse mandarão aqueles que são realmente ricos, não em dinheiro, mas naquilo em que deve abundar quem é feliz - uma vida boa e sensata. Se, porém, os mendigos e os esfomeados de bens pessoais entrarem nos negócios públicos, pensando que é daí que devem arrebatar 
o seu benefício, não é possível que seja bem administrado. Efetivamente, gera-se a disputa pelo poder, e uma guerra dessas, doméstica e interna, deita-os a perder, a eles e ao resto da cidade (PLATÃO, 2007, p. 216) ${ }^{10}$.

A seguir, Platão apontou a posse da dialética como riqueza acima da prática do poder, mediante pergunta (que atribui a Sócrates e este a seu interlocutor Glauco): "Achas então que a dialética se situa para nós lá no alto, como se fosse a cúpula das ciências, e que estará certo que não se coloque nenhuma outra forma do saber acima dela, mas que representa o fastígio do saber?" (PLATÃO, 2007, p. 232). De imediato, emerge a conclusão: "É também a melhor prova para saber se uma natureza é dialética ou não, porque quem for capaz de ter uma vista de conjunto é dialético; quem não o for, não o é" (p. 234-235).

À época de Platão, divisibilidade de ideias, a presumir a própria dialética como sua fonte, não teria tido como emergir enquanto "incontinuidade" por entre categorias e "contato" por entre suportes reais destas categorias, bem como mediação qualificadora de concepções, o que significou abertura de flancos a críticas já em Aristóteles. Posteriormente, com os neoplatônicos Plotino e Proclo, tal ausência de mediação acabou aprofundada e, com isso, "incontinuidade-contato" deixou de encontrar oportunidade histórica para se desvelar como especificidade dialética, facultando certa licença para realçar determinada especulação filosófica - aquela de que

10 Cumpre rememorar que Platão (c.427-c.347 a.C.) nasceu e conviveu ao longo da derrocada final de Atenas (431-395 a.C.), embora, anteriormente (479-431 a.C.), tivesse sido a mais representativa das cidades-Estado da Antiguidade Clássica. 
tudo emana do Uno. Tal oportunidade somente viria a ocorrer catorze séculos à frente, quando Marx abriu espaço para incidir em dialeticidade a prática revolucionária de desapossar fontes (estritamente objetivas) dos meios de vida, fazendo com que proprietários destas fontes se vislumbrem ao menos ameaçados de adentrar o "modo de existir "privacional", (vazio, imaterial e não sensorial), mesmo que, inclusive a Marx, este modo fosse ainda inacessível enquanto categoria de pensar.

Quanto às críticas, originárias já em Aristóteles, há duas restrições a propósito da pertinente procedência e a serem examinadas: (a) certa autoentrega à dominação cultural, recorrentemente irreconhecível por até intelectuais críticos, tem induzido enxerto de objeções, seja em cepa originariamente sofista, mediante procederes racional-hedonísticos, seja em cepa formal-logicista, mediante procederes desde aqueles dos estóicos até os de seguir as modernas regras cientificizantes do método; e, (b) a "situação epistêmica" do observador tem incidido em uma insignificância também ainda irreconhecível, por coincidir, seja com um inexpressivo ponto da totalidade real-concreta, seja na circunstância de se estar do lado de fora de toda especificidade; tal "epistemia" tem feito com que o específico não passe de uma totalidade cujos componentes interiores permanecem não observados, além de conterem residuais incertezas quanto às suas possíveis influências na totalização.

Quanto a existir abertura para realçar esta ou aquela especulação filosófica, trata-se de avançar em procederes que contribuam, ainda que não propositadamente, para a ultrapassagem do condicionamento originário da "situação epistêmica" do observador a se pautar pelas modernas regras cientificizantes do método em humanidades. A validade de uma tal pauta 
decorre de dominação cultural que condiciona a aplicação da lógica, mediante pressuposição, em vez de produção, de premissas acriticamente fundamentadas. Já estas premissas, ao contrário dessa validade e mesmo que de antemão presumidas, compõem a totalidade histórica que jamais deixa de se encontrar aberta ao irrestrito, ao ilimitado e ao indeterminado. Caso tais premisssas estivessem assim abertas, o proceder de chegar até elas teria de ocorrer como imersão em um miolo problematizado da mesma totalidade e o resultado desta imersão significaria uma produção de alcance endógeno.

Em desfecho, não causa estranheza que a pressuposta fundamentação do teor de premissas incida em meras obviedades (exemplo: todo homem é mortal; Sócrates é homem) ou denote ser artifício originário de dominação cultural, argumento de autoridade, etc, [ex.: “(...) senhor e escravo têm o mesmo interesse" (ARISTÓTELES, 2007, p. 54)]. Alterinamente, fundamentar o teor de uma assertiva implica "incontinuidade" abstrato-representativa e "contato" entre reais-concretos (coisas, entes, fatos e fenômenos), incidindo-se na forma como "incontinuidade-contato" esteja a mediar inserção de inequívoca qualidade dialética por entre a infinitude vazia da "escassez criada" e cada real-concreto em apropriação. Todavia, ao prevalecer aquele artifício, fundamentar premissas incidiria em proceder unilateralmente, o que equivale a inescapável violência empírico-analítica. Já esta violência decorreria de experimentação, seja esta efetiva (sempre e de antemão autojustificável em relação à natureza livre, além de insistentemente reivindicada em relação à humana), seja presumida (resultados de experimentos têm sido interpretáveis de forma alheia às circunstâncias em que acabam objetos de saber, peculiarmente ao permanecerem assim alheados a respeito de procederes cuja qualidade, ainda que favoreça cientificidade, seja inconveniente à dominação cultural). 
A contribuição de Platão precisa ser admissível como deflagratória, pois se trata da primeira e já técnico-metodicamente rigorosa descrição do proceder dialético. O teor dessa descrição cumpre ser destacado.

“(..) dividir (a ascese da alma enquanto
ideia) segundo gêneros e não assumir
como diferente a mesma forma, ou
como idêntica uma forma diferente"
(apud ABBAGNANO, 2007, p. 316.
São nossos os termos entre parênteses).

A ideia a ser assim dividida há de incidir, mesmo que em alcance ainda hipotético, naquela referente à dinâmica do desejo ou do interesse por poder em sentido amplo. Essa ideia tem como ser divisível entre duas formas: (a) aquela do "gênero-propriedade" (objeto de desejo já realizado); e, (b) aquela do "gênero-escassez-criada" (objeto de desejo ainda irrealizado ou irrealizável). Então, não cabe assumir como diferente a mesma forma (a forma-propriedade é a mesma, seja a referente a um bem de raiz, seja a um direito), nem como idêntica uma forma diferente (a forma de objeto de desejo não realizado ou irrealizável - idêntica àquela da infinitude da "escassez criada" - não coincide com aquela de objeto de desejo já realizado).

Certa mudança na proposta de Platão vai emergir na conceituação dialética dos procederes expostos por Huisman (2004, p. 785) como "exercício dialético" dos pensadores neoplatônicos Plotino e Proclo. Esse exercício foi traduzido (do latim até ao português) nos seguintes termos:

utiliza o método platônico da divisão para distinguir as espécies de um gênero, para defini-las e para chegar aos gêneros primeiros; com o pensamento faz combinações complexas 
desses gêneros, até percorrer todo o domínio do inteligível, depois, por caminho inverso, da análise, volta ao princípio (HUISMAN, 2004, apud ABBAGNANO, 2007. p. 316).

Quanto à especificidade de tal proceder, a divisão significa chegar aos componentes (espécies) de um gênero. Assim, a exemplo dos gêneros inerentes à socrática dinâmica do desejo, há real-concreto apropriado e há "escassez criada", os quais têm como cada qual ser dividido. Para tanto, real-concreto apropriado é definível como objeto de desejo já realizado e a ter "modo de existir "presencial",; e, "escassez criada" é definível como necessidade a estar histórico-culturalmente engendrada e tem "modo de existir "privacional". Assim procedendo, as espécies acabam pensadas, ao se indagar: o que corresponde a objeto de desejo já realizado e tem "modo de existir "presencial"? E: o que perfaz necessidade a estar histórico-culturalmente engendrada e a ter "modo de existir "privacional"'? Então, as respostas levam necessária e suficientemente aos gêneros (real-concreto apropriado e "escassez criada"), constatando-se que eles perfazem, complexamente, gêneros primeiros (não há a considerar outros gêneros mais abrangentes do que eles) em todo o domínio do inteligível (o âmbito da dinâmica do desejo, projetado em uma pólis ideal, apesar de presumidamente sustentada por escravos). Retorna-se, assim, ao princípio (o uno da dinâmica do desejo).

E acrescenta Abbagnano (Ibid.):

Aqui o método platônico da divisão, que para Platão é o segundo momento da dialética, tornou-se o primeiro e a ele foi acrescentado, como segundo momento, "o retorno ao princípio"[...]. 
O primeiro momento em Platão tinha como incidir na ideia socrática da dinâmica do desejo e o segundo na divisão dessa ideia segundo os gêneros de um real-concreto apropriado e da "escassez criada". Ambos e somente eles esgotam a dinâmica do desejo - este, a coincidir com a pólis ideal, ou seja, com a plena certeza de fontes dos meios de vida (terras e escravos, à época) no exterior do próprio desejoso. No caso dos neoplatônicos, o primeiro momento é o da divisão dos gêneros, chegando a espécies (subgêneros), cuja interpretação - análise e síntese - faculta perceber que os gêneros são primeiros, dado que o Uno é a pertinente procedência.

Há uma passagem de Williams (2000), em que a divisão de uma linha deve ser pensada, em acordo com ambos esses momentos históricos na explicitação do proceder dialético. Tal linha é dividida segundo dois domínios da ideia platônica que representa o mover-se da ascese da alma. Por sua vez, este movimento tem origem na experiência do cotidiano (as sombras da caverna) e segue em direção a "mais alta" realidade (aquela iluminada pelo fogo no exterior da mesma caverna) - questão que emerge ao menos candidata a assunto socrático do próprio Platão.

Temos que imaginar uma linha dividida em duas secções. A parte de cima corresponde ao conhecimento, e, também, portanto, àquelas coisas que podemos conhecer; a parte mais baixa corresponde à opinião, e àquelas coisas sobre as quais não podemos ter nada melhor do que opinião. Essas duas partes são novamente divididas em subsecções. Quando consideramos essas subsecções, a ênfase não é tanto nas diferentes coisas das quais podemos ter conhecimento 
ou opinião, mas, antes, em métodos mais ou menos diretos de adquirir conhecimento ou opinião (WILLIAMS, 2000, p. 45-46. Grifos nossos).

Tirante à interpretação do proceder dialético constante desta citação, a ênfase recai sobre filosofia dialético-metódica nos níveis das subseções. Nestes níveis, à época, era impossível que entrasse em cena "incontinuidade-contato" como dialeticidade da razão a mediar aspectos da então admitida ascese da alma, em cuja depuração inexistia alteridade de entendimento quanto a fim-começo ou começo-fim que, na interioridade do próprio pensar, demarcasse passagem, não apenas da opinião para o conhecimento ou vice-versa, como também de um para outro dos métodos de adquirir opiniões e/ou conhecimentos. Em tal circunstância, o ponto de partida teria que residir na socrática dinâmica do desejo, desde que pertinente à especificidade de possuir fontes de meios de vida no exterior do próprio desejoso, pois tal dinâmica sempre houve de perfazer real-concretude, cujo significado, para a qualidade do proceder dialético, seria constituir-se tanto mediação quanto divisibilidade técnica ou metódica (razão dos grifos na citação acima), atendo-se, no âmbito do mundo sensível, a estritas diferenças - a nada mais do que "doxas" (opiniões) em Platão.

$\mathrm{Na}$ atualidade, caberia sugerir que, à época, a ideia da dinâmica do desejo precisasse se originar no "sei que nada sei" (apenas acredito saber) do Sócrates real, em vez de na ascese da alma do Sócrates apropriado por Platão. É que, até hoje, "incontinuidade-contato" por entre modos de existir sequer ameaçou se tornar via intelectual-produtiva de opiniões, de conhecimentos, ou ainda, das próprias vias ou métodos. 
Adotando-se tal sugestão, a ideia de como proceder para que, epistemicamente, um real-concreto seja concebido como um todo - restrito, delimitado e determinado - não prescindiria do "modo de existir "privacional" da "escassez criada". Tal ideia sempre houve de emergir no bojo desta escassez, cujo modo de existir tem identidade a toda prova, dada a circunstância de que subsiste como "não ser" (como vazio, imaterialidade ou "essência" imediata da "necessidade superior”, de cujo vácuo a pessoa há de horrorizar-se por significar impossibilidade de ilimitar o poder enquanto transferência para outrem do atendimento das demais necessidades próprias). Trata-se de identidade que tem sido propriamente criada ao longo da "historização" em que superioridade cultural se impôs de forma dominante. Em prol desta (talvez já) hipótese de não ser prescindível um tal proceder com qualidade dialética, cabe visitar e atualizar o "parricídio do nada" (o platônico assassinato de Parmênides enquanto pai da concepção do "não ser”). Assim, Platão

(...) admitiu o ser do não ser e definiu o nada como alteridade: "Resulta que há um ser do não ser, tanto para o movimento quanto para todos os gêneros, já que em todos os gêneros a alteridade, que torna cada um deles outro, transforma o ser de cada um em não ser, de modo que diremos corretamente que todas as coisas não são e ao mesmo tempo são e participam do ser" (apud ABBAGNANO, 2007. p. 810. Grifo no original).

Ainda que se suspeite de mera paralogia, "o ser do não ser" constante dessa citação teria também como incidir na insignificância da "situação epistêmica" do observador, a 
qual, não apenas se desfaz como pretensa topocentria na (inevitavelmente aberta) realidade, como também coincide com o "fora das especificidades", vale dizer, com o vazio, a imaterialidade ou com o imediato e imperceptível modo de existir da "necessidade superior", cujo alcance político tem como se criar dissenso contínuo, o que houve de ser feito às custas da vitoriosa denegação da gratuidade dos excedentes da inequívoca produção dos derrotados.

Então, é necessário partir do que demarca a "situação epistêmica" duma fonte de procedimentos, fonte que ainda não vislumbra que se encontra imersa em absoluta insignificância, vale dizer, subsumida em um "nada substancial" (imaterial infinitude dos objetos de desejo ainda não realizado ou irrealizável). Trata-se de insignificância que sempre foi a ainda irreconhecível condição de quem se restringe a nada mais do que lógico-formalizar. Ademais, é condição a ter que se desvelar, por força de ser detentora da única identidade de fato possível - aquela ininterruptamente criada da imaterialidade da escassez em si mesma. Assim, por hipotético como isto ainda há de acabar formalizado, procedimentos lógicos se caracterizam pela serventia de prevenir aquela descoberta, preterindo-a ou a reduzindo à condição de "lacuna metafísica".

Já a respeito de tal "lacuna", o proceder especificamente dialético faculta perceber que por entre a ideia da ascese da alma e cada um dos dois saberes genéricos que a constituem, bem como por entre estes mesmos saberes genéricos, emerge o que cumpre ser denominado como questão erística ou disputacional.

Como começa ou termina a opinião (talvez passível apenas de diferença) e tem início ou fim o conhecimento (talvez compreensivo de estrita identidade)? E, dado que ambos 
compõem o todo (a própria ideia platônica da ascese da alma), como é que diferença e identidade não se misturam e o próprio todo seja referência da ideia de tal ascese?

Um "vazio" (lacuna) há de acabar presumido para perfazer começo-fim ou fim-começo de cada diferença e de cada identidade, para que a ideia corresponda ao todo (forma superior).

A ideia assim compreensiva de conhecimento e de opinião, caso tivesse que coincidir com a abstrata-representação da "physis" (substrato cósmico que é permanente) na filosofia clássico-antiga, haveria de adentrar tal "vazio" e este de incidir em "meta" (por além do substrato em causa), vale dizer, tornar-se-ia "metaphysis". Para Platão, tal "vazio" deveria ser a alma e a ascese desta seria um inercial mover-se tirante àquele do substrato cósmico a se eternizar.

Ademais, esse mesmo "vazio" houve de permanecer como usurpação da subjetividade e da real-concretude humana de quem soe observar e ser fonte de saberes. Tal usurpação, à base das modernas regras cientificizantes do método, tem incidido na supressão do sujeito em relação a objeto(s), ou seja, na denegação da teoria do conhecimento. Em contrapartida, a fonte de saberes tem precisado se valer da propriedade do que lhe advém do exterior de si mesma, propriedade que lhe serve de orientação para garantir atendimento da "necessidade superior" de poder ou de contar com garantia de pronto e incondicional atendimento das demais, a partir das básicas e da espécie.

Então e em tese, pessoas têm tido que existir, de uma parte, a perfazerem uma pretensa identidade que coincide com infinitude de objetos de desejo irrealizado ou irrealizável (de propriedades externas à própria pessoa), e de outra 
parte, a se apresentarem com diferenças que decorrem de jamais deterem suficiência de reais-concretos correspondentes a esses mesmos objetos. Em ambos os casos, há de subsistir descontinuidade ou não nulas duração e distância por entre a "escassez criada" (fundamento da identidade a toda prova) e o cotidiano (fundamento das diferenças). Por seu turno, tal descontinuidade há de perfazer a insignificância da "situação epistêmica" - esta, enquanto efetividade (caso de poderosos que usurpam o espaço vital de crianças e de suficiências do coletivo) ou mera pretensão (caso de adultos, enquanto apenas forçosamente produtivos).

Garantir o atendimento da "necessidade superior" coincide com impedir que "diastemia" sirva como alteridade de condição que faculte à razão da fonte de procedimentos se inferir por entre o "modo de existir "privacional"” (vazio, carencial e imaterial) da "escassez criada" e "o modo de existir "presencial"” (plenista, disposicional e material) dos reais-concretos apropriados. Entretanto, a oposição entre a insofismável identidade do modo de existir da "escassez criada" e a diferença do modo de existir de um real-concreto apropriado enseja que "diastemia" acabe em alteridade de circunstância para a razão nela se inferir dialeticamente intelectual-produtiva.

"Situação epistêmica" é própria à pessoa ainda autoinsustentável. Valer-se dessa situação para garantir atendimento da "necessidade superior" tem incidido em procedimento exclusivista. Exclusivismo epistêmico é situação, a partir da qual, conceber ideias desanda em unidimensionalismo ainda irreconhecível.

O "modo de existir "presencial" é bastante aos objetos do saber epistemológico, graças a delimitações superficial-externas, aparentes e perceptíveis dos reais-concretos apropriados, delimitações que hão de adequar-se àquelas do alcance 
humano da sua fonte. Assim, exclusivismo do "modo de existir "presencial"' (entre detentores de garantia de atendimento da "necessidade superior") e devotamento à "criação de escassez" com seu "modo de existir "privacional" (entre despossuídos), ambos têm denotado insistência em anular a fonte socrática da conduta moral "que brota do interior do próprio indivíduo".

Deve haver uma espécie de elo ainda não encontrado na busca de especificidade dialética enquanto qualidade no conceber ideias. Tal elo terá que responder à circunstância de a conflituosidade, já em Heráclito, e a radicalidade da supressão de reais-concretos apropriados (comunismo), ainda em Platão, coadunarem-se com questionamentos socráticos às inerências da dinâmica do desejo, a par de que teores correspondentes a tais inerências ainda deverão ser inferidos como saberes condicionados por "epistemia". Quanto ao comunismo em Platão, já Aristóteles (2007. p. 93) considerou-o errado, pois entendia que (sic): “[...] não são as propriedades e sim os desejos dos homens o que precisa ser igualizado, o que é impossível sem uma educação estabelecida por boas leis". Entretanto, no superior e eterno éter da aristotélica dominação cultural, expansão de propriedades sempre atendeu à necessidade de se ter incomensurável certeza do atendimento das demais, a começar pelas básicas e, sobretudo, por aquelas da espécie.

A esta altura da busca da especificidade dialética enquanto qualidade no conceber ideias, outra etapa já seria admissível, a partir da suspeita de que exclusivismo epistêmico e qualidade dialética não tenham como se coadunarem. Com efeito, dialética provém da junção das palavras "diá" (através) e "légein" (falar) e seu significado implica o coletivo. Já a respeito de tal suspeita, cabe apontar que o "modo de existir "privacional"" 
é próprio da insuficiência no atendimento das necessidades da espécie, ou seja, é próprio da insustentabilidade coletiva; porém, esse mesmo modo deverá conter delimitações que adentrem seu próprio bojo, as quais terão de coincidir com o possível atendimento daquelas necessidades em reciprocidade de coerência com o intercâmbio orgânico com a natureza. Cabe também apontar que há o "modo de existir "presencial"" do corpo e dos meios de mantê-lo saudável, cumprindo ao menos vislumbrar "incontinuidade-contato" por entre a diferença do "presencial" e a identidade a toda prova do "privacional".

"Incontinuidade-contato" ainda terá como perfazer alteridade de circunstância para a razão inferir sustentabilidade também coletiva. Já esta circunstância haverá de incidir em forma "diastêmica" e significará oportunidade para prevenir inércia, por além do que é natural, da autoinsustentabilidade da pessoa. Na pregressa e recorrente ausência desta prevenção, o todo daquela fonte houve de sobrepor-se a outros todos, o que tem ocorrido na insignificância deste ou daquele todo, dentre incontáveis outros, da realidade inteira.

Situação assim alterina ainda não teria chegado a ser objeto nem mesmo de especulação filosófica, conquanto tenha sido como que tangida em uma primeira contribuição de Sócrates e, apenas na contemporaneidade, Marx dela se tenha aproximado ao propor despossessão das (tão só objetivas) fontes dos meios de vida. 


\section{Categorias fenomenicamente compreensivas do que está escondido sob o que está manifesto}

Ao abordar o método em fenomenologia e assumi-lo como filosófico, Novaski (2007, p. 79-85) recorre à dualidade entre as abstrações do manifesto e do oculto.

Mostrar e ocultar, eis aí a estrutura de todo fenômeno. A conjunção $e$ entre os dois verbos é proposital: é para enfatizar a simultaneidade que ocorre entre esses dois componentes de fenômeno: ao mesmo tempo que ele se manifesta, se esconde; ele sempre se oculta nas dobras daquilo que se mostra diretamente. (...) com efeito, na estrutura do fenômeno reside o pressuposto inicial e, por ser pressuposto, não há nada antes dele que o explique. E certamente há uma inquestionável coerência do método com esse pressuposto: se há algo sempre e sempre oculto em tudo o que se me mostra, então estou constantemente obrigado a decifrar o que não consigo sequer lobrigar nas dobras do aparente. Ora, decifrar é o mesmo que interpretar e interpretar, por sua vez, quer dizer desocultar o escondido, trazer à tona o que está no fundo, revelar o velado, denunciar o dissimulado. Esse é o método fenomenológico, embutido na descrição que porventura queiramos fazer do que quer que seja sob nossa percepção (NOVASKI, 2007, p. 81-82. Grifo no original). 
Ao longo da leitura desta citação, é-se desafiado a interpretar a própria interpretação, por alheamento ao pressuposto do oculto - ao oculto do próprio oculto. Antes de tudo, infere-se que a "nossa percepção" tem pontos cegos ou costas, por pressupor, de uma parte, recorrente preterição do significado da "situação epistêmica" em que se encontra o observador, e de outra, o mover-se dialético do interpretar por si mesmo. Com efeito, tal percepção não tem decorrido de se questionar ausência de delimitação enquanto fim-começo ou começofim por entre as abstrações do manifesto e do oculto e sem que o próprio método filosófico tenha sido desafiado a substituir esta mesma ausência. Assim, e inclusive para prevenir "lacuna metafísica", cumpre admitir que interpretar signifique remover o citado pressuposto de cada concepção, não apenas às costas da acepção aristotélica de dialética enquanto lógica do provável, mas também incidindo no entendimento da própria dialética como proceder abstrato-intelectualmente delimitativo ou produtivo. À base de tal proceder, remove-se aquela (escondida) pressuposição. Ademais, não há de ocorrer alheamento à circunstância em que o método sempre se esgotou na relação entre processo e resultados deste, preterindo-se ponto de partida ou primordialidade de princípios, inclusive em humanidades. Adentra-se, enfim, ao miolo de determinado fenômeno, aquele da sociabilidade humana, em que, a princípio, o método fenomenológico acabaria por até mesmo se substancializar ou se essencializar.

Ao se interpretar sociabilidade humana, infere-se dualidade que é inerente ao próprio mover-se da dialetização do mundo, dialetização a ser assumida enquanto história das interações entre seres humanos e entre estes e a natureza livre. No caso, o pressuposto apontado por Novaski há de incidir em "vontade" a se "historicizar" como autoimpulsão subjetiva que se manifeste parcial e efetivamente geradora 
de gratuidade em reciprocidade de coerência com intercâmbio orgânico com a natureza humana e livre. Tal "vontade" será inferível como inescapável princípio à gnoseogênese da singularidade subjetiva. Isto, porque o "“ausencial' modo de ser" da "vontade" terá de coincidir com o direto exercício das funções que se voltem para atender necessidades naturais, peculiarmente as de sustentação da espécie, exercício cujo sentido se projeta do exterior para o interior da pessoa, da prole e/ou do coletivo, contrariamente ao processar-se do sentido da vivenciada sensação das necessidades. Assim, perceber a condição subjetiva de tal contrário, por aquém e diversamente da inversão dialética procedida por Marx com sua objetiva práxis revolucionária, ainda virá a ser antítese que, apesar de ainda não dialetizada nem mesmo como lógica do provável, haverá de colocar-se como delimitação no bojo da infinitude do "privacional' modo de existir" da "escassez criada". Dada a direta imperceptibilidade desta infinitude e da "vontade" subjetivamente assumida, passa a ser possível inferi-las enquanto inequívocas e imediatas identidades. Em desfecho, cabe interpretar o significado da remoção do pressuposto inicial do fenômeno, remoção que, em princípio, deve ocorrer a cada concepção em destaque (entre aspas, ao longo desta investigação).

Entrementes, tem havido outro pressuposto que persiste preterido (às costas, em ponto cego ou por aquém do método fenomenológico) e que condiciona percepções cuja procedência se dá a partir de "situação epistêmica" do observador. Trata-se do caráter íntegro da individuação, o qual perfaz a pessoa, o coletivo natural-mínimo e, por potencial que ainda o precise ser, processos humanizadores acentuadamente complexos. A historiedade desses processos permanece meramente futura ou a depender do exercício de funções, cuja efetivação há de significar alteridade de relações transpessoais. Quanto a esta 
alteridade, inferem-se apenas as (ainda e meras) potencialidades da "afetividade" e da "razão" - "razão", por aquém de racionalidade em relação a fins e valores, e "afetividade", por aquém de sociabilidade imersa na infinitude da "escassez criada".

Para precipitar tal historiedade, cumpre assumir a (acima mencionada) “'ausencial' forma de ser por entre sentidos”, na perspectiva de dinamizá-la enquanto intencionalidade pedagógica a se efetivar na "individuação íntegra" do egresso. Porém, o caráter (assim "ausencialmente") íntegro de tal individuação carece de ser inferido enquanto ainda em "formação". Por sua vez, esta mesma "formação" há de ocorrer por entre uma comunhão de necessidades (a se manifestar do humano para outridade deste, para o inumano inclusive, e no sentido de atrair o que as atende para o interior da pessoa), e, uma conexão de funções (a se manifestar em sentido coerente com tal atração).

A individuação, a se assumir assim íntegra, é ainda meramente futura, devir ou "não ser" em relação a tudo que ora está manifesto. E este tudo ainda não passa de um vazio de produtores e de produtos, os quais permanecem represados ou contidos em estritas potencialidades.

Valendo-se das concepções já descritas, "formação" virá a ser concebida como capacitação a se aperceber e se observar na situação por entre dois sentidos que se encontram fenomenicamente escondidos e, por isso, carentes de interpretação. "Formação" cumpre ocorrer como “"ausencial' forma de ser por entre sentidos”, na convergência entre comunhão de necessidades e conexão de funções, assim como em reciprocidade de coerência e pertinência quanto à condição vital-básica das necessidades e à base de direto e/ou indireto intercâmbio orgânico com a natureza. 
Ainda a respeito do caráter íntegro da individuação logo acima inferida, é necessário entender que integridade de caráter adentra incompatibilidade com totalização epistemicamente compreendida, uma vez que, neste alcance de compreendida, a situação, a partir da qual são projetadas as formas de existir, é "historizada" sob radical descolamento em relação ao significado de inserção "por entre opostos", inserção que, alterinamente, lhe facultaria compor uma totalidade. Tal descolamento, que é traduzido por "epistemia", tem coincidido com a irrelevância quanto a diferenciar um todo (compreensão abstrata) de uma totalidade (individuação íntegra), diferenciação que "não convém que ocorra", ao se buscar esta ou aquela especificidade, nem mesmo como fronteiriço começo-fim (ou fim-começo) de componentes daquele mesmo todo. Por sua vez, uma especificidade, ao subsistir epistemicamente aquilatada, tem tido que perfazer um todo, cuja interioridade ainda precisa permanecer irreconhecível naquilo que residualmente o constitua. Por isso, esta interioridade acaba positivo-cientificamente aceita por conhecida, à conta das funções do todo, as quais, por seu turno, precisam coadunar-se com artifício. Já este artifício tem sido extrinsecamente determinado pelo alcance meramente criado da necessidade de o atendimento das demais - as naturais-básicas e da reprodução da espécie - estar "favas contadas", mediante "cercamento" das fontes dos meios de vida e sujeitação de outrem a contribuir para alargar este mesmo cercamento, sob pena de a subsistência dos sujeitados restar de antemão impossibilitada. Prevenir riscos quanto a contar com essa contribuição tem provocado recorrente e predizível obsessão em fragmentar toda especificidade, inclusive na perspectiva de determinar um limite interior.

Em ciências naturais, forma vem incidindo na delimitação aparencial-externa das especificidades, independentemente do 
grau de fragmentação ao qual estas correspondam. Em ciências humanas, todavia, tal delimitação está a acontecer alheadamente à “"ausencialidade' do modo de ser” dos sentidos pelos quais teleconvergem o exsurgir das necessidades e o mover-se das funções de as atender. A necessidade cultural-civilizatória de contar com incondicional garantia de atendimento das demais necessidades, das naturais-básicas antes de todas, adentra imaterialidade cujas fronteiras externas chegam a tanger enigma e até mesmo mistério. Já as funções têm ocorrido concretamente delimitadas e o afinamento delimitativo tem ocultado a concretude dos seus suportes, além de estarem a incidir em objeto de pesquisa em perspectiva experimental-epistêmica de marginalização, informalização e sócio-subjetivação das pertinentes (e violentadas) essências funcionais.

À medida que se conceitue o ser humano com base em forma de ser por entre os sentidos de uma comunhão de necessidades em "incontinuidade-contato" com uma conexão de funções voltadas para atendê-las, vislumbra-se sua (ainda meramente potencial) individuação, singular e/ou coletiva, como "configuração" de "incontinuidades-contatos" dialeticamente situadas - cada uma destas por entre uma necessidade e o exercício da função que a atende. Assim, a totalidade se torna inteira, havendo reciprocidade de coerência e de pertinência entre modos-e-forma de ser. Todavia, à conta da recorrente mediação da dinâmica do desejo e do apoio no " "presencial' modo de existir" da materialidade finita, o "privacional' modo de existir" da infinitude da "escassez criada" tem usurpado a não aparência do " "ausencial' modo de ser" e, com isto, represado a efetivação do potencial de inteiração das possíveis individuações.

Visualizar a situação da "forma de ser por entre sentidos" presume inequivocação quanto a produzir abstrato- 
intelectualmente, conciliando-se método com sua procedência e com resultados cuja obtenção ele condicione. Resta, então, descabido falar de "modo de produção", uma vez que, por si mesma, produção já é via processual e, por isso, "modo" tem incidido em algo de pleonástico e de antemão supérfluo - em algo irracional tal como tem sido o exercício do poder, a usurpar o exercício das funções organicamente compromissadas com o atendimento do alcance vital-básico das necessidades humanas. Cumpre enfatizar tal conciliação metódica e, especificamente, enquanto ela há de coincidir com princípio humanizador. É o que urge ocorrer, a partir da ultrapassagem do período da natural autoinsustentabilidade da prole e, imprescindivelmente, ao limiar da assunção da adultez. Assim, e não por mera coincidência, este limiar e a frequência à universidade perfazem oportunidade cuja postergação tem feito com que o discurso da qualidade, peculiarmente o da excelência do alcance superior do ensino, chegue a adentrar o perfil de "crime de colorinho branco".

Em desfecho, há de emergir o aperceber-se da "razão material-comunicativa". Trata-se de um aperceber-se de modo objetivado, no âmago da totalidade e fora das subjetividades humano-singulares, coincidindo com intercâmbio de utilidades e de ideias. Já este intercâmbio, por restar represado em suas potencialidades, ainda não logrou favorecer pessoas e organizações no sentido de ao menos vislumbrarem a recorrente circunstância em que se encontram imobilizadas - por entre um dilema de subsistência e uma questão disputacional.

O dilema compreende opostos: (a) o bem-estar individual e geral, que ora é vivenciado, teria como continuar possível apesar de uma inaudita redução do esforço que vem sendo despendido sob coerção institucional e sujeitação informal; 
ou, (b) esse mesmo bem-estar seria, alterinamente, várias vezes maior, se esforço equivalente ao já em efetivação contasse com fissuras, brechas ou poros para ser exercido de modo parcial-opcionalmente gratuito.

Questão disputacional tem a ver com a complicação diversamente de complexidade - em que se insere a percepção dos teores desses mesmos opostos, pois a tentativa de assumilos se depara, de uma parte, com renitente desinteresse dos detentores de poder, e de outra, com inacessibilidade histórico-culturalmente criada para pessoas que mais necessitam de os perceber e interpretar.

Em suma, o acesso a tal "razão" sintetiza a necessidade de educar e a função de atender esta mesma necessidade, ao tempo em que projeta os teores da "relação entre prole e quem a sustenta, direta ou indiretamente" como fonte de inclusive instintiva "alfabetização" (instrumentalização quanto a produzir abstrato-intelectualmente). 